\title{
Deoxyribonucleic Acid Relatedness of Strains of Yellow- Pigmented, Group D Streptococci
}

\author{
DAVID H. VAUGHAN, W. S. RIGGSBY, AND J. ORVIN MUNDT \\ Department of Microbiology, University of Tennessee, Knoxville, Tennessee 37916
}

\begin{abstract}
Deoxyribonucleic acid (DNA) homology was used to examine genetic relatedness among 25 yellow-pigmented strains of group D streptococci and to clarify the possible genetic relatedness of these strains to Streptococcus faecium and Streptococcus faecalis. In all cases, the DNA of the yellow-pigmented strains hybridized with the DNA of $S$. faecium and $S$. faecalis at a level of less than $25 \%$. Based on median thermal dissociation temperatures $\left(T_{m}\right.$ 's) and hybridization tests, the yellow-pigmented strains were divided into two groups (I and II). DNAs of strains in group I had relatively low $T_{m}$ 's and did not exhibit significant homology with DNA of the herein designated type strain (ATCC 25788) of $S$. faecium subsp. casseliflavus. The DNAs of group II strains, on the other hand, exhibited high $T_{m}$ 's and had a high degree of homology with the DNA of the type strain of the above-mentioned subspecies. Three physiological traits were found to be peculiar to group II organisms: ability to grow in the presence of $6.5 \%$ sodium chloride, inability to ferment sorbitol, and inability to decarboxylate tyrosine. It is proposed that the group II strains constitute a separate and distinct species. Because the strains presently placed in this species include the type strain of $S$. faecium subsp. casseliflavus Mundt and Graham, the name of this species, according to the rules of the Bacteriological Code, is Streptococcus casseliflavus (Mundt and Graham) comb. nov.
\end{abstract}

Mundt and Graham (11) proposed the name Streptococcus faecium subsp. casseliflavus for group D yellow-pigmented streptococci which were isolated from plants $(11,12)$. Taken into consideration for the establishment of this subspecies were its pigmentation, physiology, and ecology, which set this subspecies apart from Streptococcus faecalis and the other subspecies of Streptococcus faecium.

In their original description of $S$. faecium subsp. casseliflavus, Mundt and Graham (11) did not designate a type strain. We are here designating as the type strain one of the strains on which the original description was based; this strain is referred to as strain 4 in this paper. The properties of this strain are described in Table 1 of Mundt and Graham (11), and a culture of it has been deposited with the American Type Culture Collection (ATCC) under the number 25788.

Since the proposal of Mundt and Graham (11), Taylor et al. (14) observed that yellow pigmentation in the group D streptococci with which they worked seemed to vary from organism to organism independent of other characteristics, thus rendering pigmentation of questionable value for taxonomic purposes.

Amstein and Hartman (1) used gas chromatography to compare the relative fatty acid composition of various strains of enterococci, includ- ing $S$. faecalis, $S$. faecium, $S$. faecium subsp. durans, and three strains of $S$. faecium subsp. casseliflavus. Based on differences between the fatty acid composition of the strains of $S$. faecium subsp. casseliflavus and that of the other strains, it was concluded that $S$. faecium subsp. casseliflavus deserved varietal (now subspecies), if not species, status.

Roop et al. (13), using deoxyribonucleic acid (DNA)-DNA hybridization, observed that an authentic strain of $S$. faecium subsp. casselifla. vus exhibited little homology with reference strains of $S$. faecium, $S$. faecalis, and S. lactis.

Most of the taxonomic studies of the yellowpigmented streptococci have included one or a very few of the yellow-pigmented strains. The principal purpose of the work reported here was to use DNA-DNA hybridization to examine genetic relatedness among a large number of these strains and to determine whether these strains are genetically related to $S$. faecium and $S$. faecalis.

\section{MATERIALS AND METHODS}

Bacterial strains. The strains used in this study are listed in Table 1 . All of the strains except numbers 12,13 , and 27 , which were obtained from W. R. Chesbro, were isolated locally from sources specified in Table 1. Strain 4 is the type strain of S. faecium subsp. casseliflavus. Strain 5 , which has cultural and physi- 
TABLE 1. Strains used in this study

\begin{tabular}{|c|c|c|c|}
\hline Serial no. of strain & $\begin{array}{c}\text { Laboratory strain designa- } \\
\text { tion }\end{array}$ & Identification & Source \\
\hline 1 & MUTK & S. faecium & Human \\
\hline 2 & MUTK & S. faecium & Human \\
\hline 3 & MUTK 60 & S. faecalis & Human \\
\hline 4 & MUTK 20 & S. faecium subsp. casseliflavus & Plant \\
\hline 5 & MUTK 21 & S. faecium subsp. casseliflavus & Plant \\
\hline 6 & MUTK & Yellow streptococcus & Plant \\
\hline 7 & MUTK 12 & Yellow streptococcus & Plant \\
\hline 8 & MUTK 31 & Yellow streptococcus & Plant \\
\hline 9 & MUTK 33 & Yellow streptococcus & Plant \\
\hline 10 & MUTK 68 & Yellow streptococcus & Plant \\
\hline 11 & MUTK 74 & Yellow streptococcus & Plant \\
\hline 12 & MUTK 559 & Yellow streptococcus & Soil \\
\hline 13 & MUTK 564 & Yellow streptococcus & Soil \\
\hline 14 & MUTK 595 & Yellow streptococcus & Plant \\
\hline 15 & MUTK 730 & Yellow streptococcus & Plant \\
\hline 16 & MUTK 41 & Yellow streptococcus & Plant \\
\hline 17 & MUTK 46 & Yellow streptococcus & Plant \\
\hline 18 & MUTK 61 & Yellow streptococcus & Plant \\
\hline 19 & MUTK 63 & Yellow streptococcus & Plant \\
\hline 20 & MUTK 64 & Yellow streptococcus & Plant \\
\hline 21 & MUTK 66 & Yellow streptococcus & Plant \\
\hline 22 & MUTK 441 & Yellow streptococcus & Plant \\
\hline 23 & MUTK 442 & Yellow streptococcus & Plant \\
\hline 24 & MUTK 443 & Yellow streptococcus & Plant \\
\hline 25 & MUTK 444 & Yellow streptococcus & Plant \\
\hline 26 & MUTK 445 & Yellow streptococcus & Plant \\
\hline 27 & MUTK 562 & Yellow streptococcus & Soil \\
\hline 28 & MUTK 627 & Yellow streptococcus & Plant \\
\hline
\end{tabular}

ological properties similar to those of strain 4 , has approximately $75 \%$ DNA homology with strain 4 (see results); therefore, these two strains are used as reference strains in the nucleic acid homology studies reported here.

Cultural and physiological characters. The cultural and physiological characters of the yellow-pigmented strains (Table 2) were determined by methods described previously $(11,12)$.

Extraction and preparation of DNA. Both unlabeled and labeled DNA was prepared by the modification described by Roop et al. (13) of the procedure of Marmur (9). With some of the yellow-pigmented strains, it was necessary to extract the DNA extensively first with phenol and then with chloroformisoamyl alcohol $(24: 1$, vol:vol) before attempting to precipitate the DNA with ethanol. The phenol used in the extraction was redistilled and saturated with standard saline citrate $(0.15 \mathrm{M} \mathrm{NaCl}-0.015 \mathrm{M}$ sodium citrate) immediately before use.

All DNA used for reassociation studies was sheared in a Raytheon model DF-101 magnetostrictive sonicator to an average molecular weight of $3 \times 10^{5}$ (13). Labeled DNA was dialyzed against $0.12 \mathrm{M}$ phosphate buffer, denatured by heating for $10 \mathrm{~min}$ at $100^{\circ} \mathrm{C}$, and further purified by passage through hydroxyapatite (Bio-Gel MT) at $60^{\circ} \mathrm{C}$. This rid the DNA of any material which bound nonspecifically to hydroxyapatite during reassociation reaction assays and eliminated most of the material which, in reassociation assays on hydroxyapatite, would give false-positive reassociation results (3).
Determination of $T_{m}$ and $G+C$ content of DNA. The median thermal dissociation temperature $\left(T_{m}\right)$ of each of the DNA samples was determined by the method of Marmur and Doty (10). Samples were dissolved in standard saline citrate at a concentration of $25 \mu \mathrm{g}$ of DNA per ml. The samples were heated in an Acta CIII dual-beam spectrophotometer equipped with a jacketed cuvette chamber and a calibrated platinum thermocouple probe which was fixed in a cuvette filled with mineral oil. The temperature was increased automatically at a rate of $0.1^{\circ} \mathrm{C} / \mathrm{min}$ through the range 25 to $100^{\circ} \mathrm{C}$ by means of a programmable Haake temperature control unit. Optical densities of each sample were recorded at every $0.1^{\circ} \mathrm{C}$ change in temperature.

The guanine plus cytosine $(G+C)$ content of the DNA was calculated by the equation of De Ley (7): $\mathrm{mol} \% \mathrm{G}+\mathrm{C}=2.44\left(T_{m}-69.4\right)$.

Reassociation reaction mixtures. The buffer for the reaction mixtures was $0.24 \mathrm{M}$ phosphate buffer. Each reaction mixture consisted of $0.33 \mu \mathrm{g}$ of labeled DNA and $167 \mu \mathrm{g}$ of unlabeled DNA in a total volume of $1 \mathrm{ml}$. Each mixture was placed in a sealed vial, dissociated by heating at $100^{\circ} \mathrm{C}$ for $10 \mathrm{~min}$, and incubated for $17 \mathrm{~h}$ (to a $\mathrm{C}_{0} \mathrm{t}$ [5] of 100 ). To correct for selfreassociation of labeled DNA, reaction mixtures were also prepared with $0.33 \mu \mathrm{g}$ of labeled DNA in $1.0 \mathrm{ml}$ of $0.24 \mathrm{M}$ phosphate buffer with no unlabeled DNA present. At the end of the incubation period, the reaction mixtures were cooled with ice and frozen at $-20^{\circ} \mathrm{C}$ until subjected to assay.

Hydroxyapatite assays of reassociation reac- 


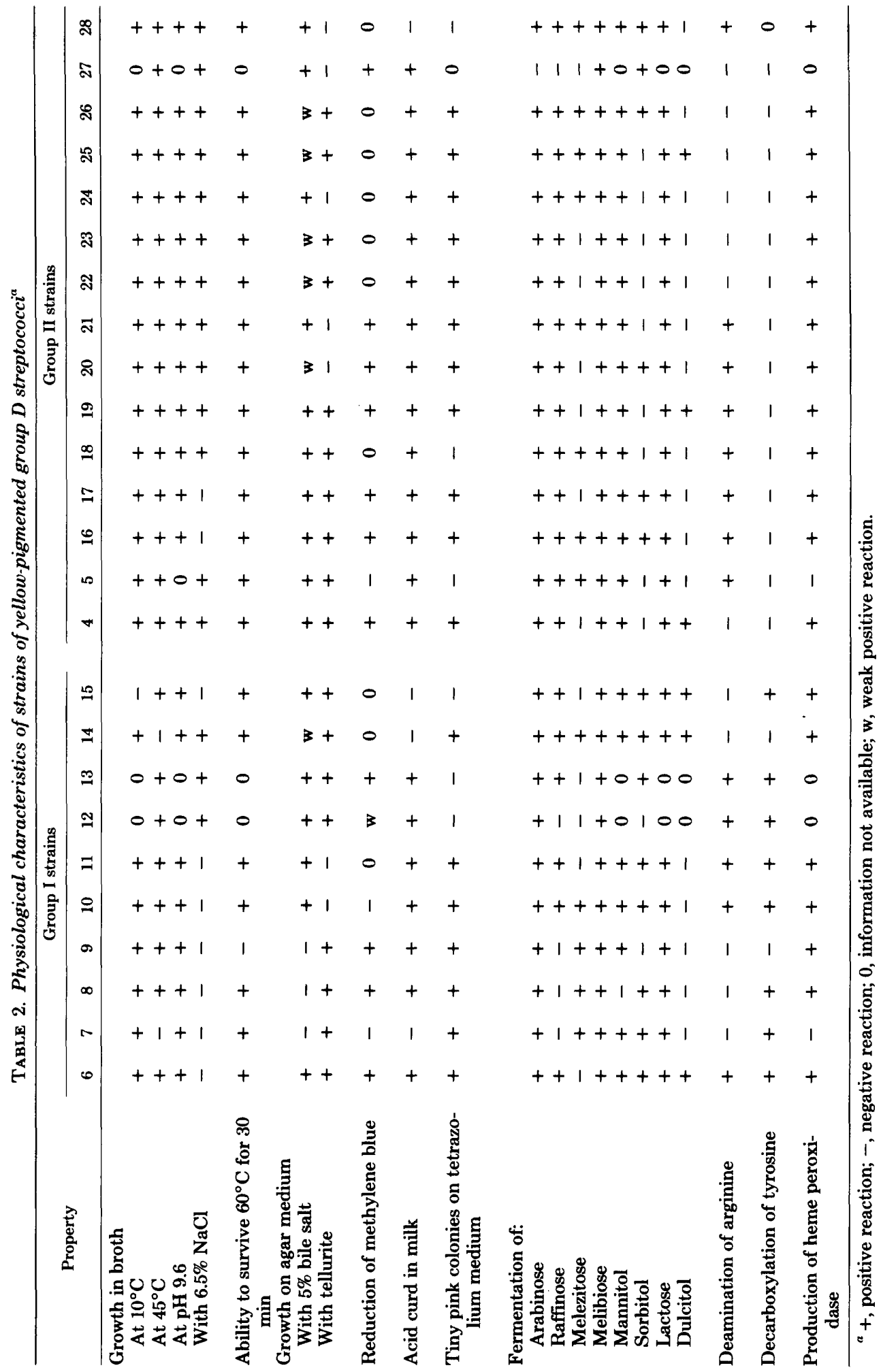


tions. Assays were carried out by the hydroxyapatite batch procedure of Brenner et al. (3). In step 1, a hydroxyapatite suspension $(0.28 \mathrm{~g}$ [dry weight] per $\mathrm{ml}$ of water) was boiled to reduce nonspecific binding of DNA (2). The hydroxyapatite solution was diluted with $0.001 \mathrm{M}$ phosphate buffer so that $10 \mathrm{ml}$ contained three times as much hydroxyapatite as was needed to bind the DNA in each reaction vial (approximately 60 $\mathrm{mg} / \mathrm{ml}$ ). In step 2 , samples $(10 \mathrm{ml})$ of the hydroxyapatite were added to $40-\mathrm{ml}$ polypropylene tubes, placed in a centrifuge maintained at $70^{\circ} \mathrm{C}$, and centrifuged at $1,000 \times g$ for $4 \mathrm{~min}$. In step 3, the supernatant fluid was discarded, and the hydroxyapatite was washed three times with $15-\mathrm{ml}$ portions of $0.12 \mathrm{M}$ phosphate buffer containing $0.4 \%$ sodium dodecyl sulfate and $0.005 \mathrm{M}$ ethylenediaminetetraacetic acid. The tubes containing the hydroxyapatite sediment were placed in water baths at 60,70 , or $75^{\circ} \mathrm{C}$, the temperature of the water bath depending on the temperature at which the reassociations were carried out. In step 4, reaction mixtures were thawed, diluted with $1.0 \mathrm{ml}$ of distilled water and $13 \mathrm{ml}$ of preheated $0.12 \mathrm{M}$ phosphate buffer containing $0.4 \%$ sodium dodecyl sulfate and $0.005 \mathrm{M}$ ethylenediaminetetraacetic acid, and mixed with the hydroxyapatite. The tubes were placed in the water bath for $20 \mathrm{~min}$ and were agitated frequently. The temperature of both the water bath and the tubes always remained above $55^{\circ} \mathrm{C}(3)$. In step 5 , the tubes were centrifuged, and the solutions were poured into scintillation vials. The hydroxyapatite was washed with $15-\mathrm{ml}$ portions of the buffer until no counts were detected in the buffer. In step 6, to determine the amount of double-stranded DNA still bound to hydroxyapatite after exhaustive washing with buffer, the washed hydroxyapatite was dissolved in $5 \mathrm{~N} \mathrm{HCl}$ and the solution was poured into scintillation vials for counting.

Thermal elution studies. To assess the thermal stability of the hybrids trapped on hydroxyapatite, the assay procedure described above was carried out through step 5 , and the DNA was progressively eluted at increasing temperature. Specifically, fractions were eluted with the same buffer used in step 4 but at temperatures above the original incubation temperature. Successive elutions were carried out at intervals of $2.5^{\circ} \mathrm{C}$ to a final value of $100^{\circ} \mathrm{C}$. The fractions eluted at each temperature were assayed for radioactivity. For purposes of graphic representation (Fig. 1 to 4), the total amount of radioactivity eluted at or below a given temperature was determined and normalized to the total radioactivity of the sample, yielding cumulative percent DNA eluted.

Assay of radioactivity. The radioactivity of the samples was assayed in a Packard Tri-Carb scintillation counter by counting the Cerenkov radiation generated by the ${ }^{32} \mathrm{P}$ in the DNA (6).

\section{RESULTS}

$T_{m}$ and $\mathrm{G}+\mathrm{C}$ content of the DNA. $T_{m}$ 's and $\mathrm{G}+\mathrm{C}$ contents of DNAs from all strains are shown in Table 3. Escherichia coli K-12 was used as a standard for the $T_{m}$ determination. The $T_{m}\left(90.2 \pm 0.2^{\circ} \mathrm{C}\right)$ determined for the strain used compared favorably with those found in
TABLE 3. $T_{m}, G+C$ content, and percent hybridization of the DNAs of group I and group II strains

\begin{tabular}{|c|c|c|c|c|}
\hline \multirow{2}{*}{ Strain } & \multirow{2}{*}{$\begin{array}{l}T_{m}{ }^{a} \\
\left({ }^{\circ} \mathrm{C}\right)\end{array}$} & \multirow{2}{*}{$\begin{array}{l}\mathrm{G}+\mathrm{C} \text { content } \\
(\mathrm{mol} \%)\end{array}$} & \multicolumn{2}{|c|}{$\begin{array}{l}\text { Hybridization }{ }^{h} \text { with } \\
\text { strain: }\end{array}$} \\
\hline & & & 4 & 5 \\
\hline \multicolumn{5}{|c|}{ Group I } \\
\hline 6 & 85.2 & 38.6 & 16 & 4 \\
\hline 7 & 83.5 & 34.7 & 19 & 9 \\
\hline 8 & 85.1 & 38.3 & 7 & 8 \\
\hline 9 & 84.8 & 37.6 & 41 & 22 \\
\hline 10 & 85.8 & 39.4 & 7 & 7 \\
\hline 11 & 84.8 & 37.6 & 26 & 22 \\
\hline 12 & 84.9 & 37.8 & 9 & 6 \\
\hline 13 & 85.0 & 38.1 & 12 & 9 \\
\hline 14 & 86.0 & 40.5 & 9 & 13 \\
\hline 15 & 84.4 & 36.6 & 32 & 22 \\
\hline
\end{tabular}

\begin{tabular}{crrrr} 
Group II & & & & \\
4 & 86.6 & 42.0 & 100 & 77 \\
5 & 86.4 & 41.5 & 75 & 100 \\
16 & 86.7 & 42.2 & 90 & 88 \\
17 & 86.8 & 42.5 & 77 & 99 \\
18 & 86.8 & 42.5 & 86 & 99 \\
19 & 86.4 & 41.5 & 87 & 77 \\
20 & 86.3 & 41.5 & 96 & 82 \\
21 & 86.2 & 41.0 & 79 & 94 \\
22 & 86.6 & 42.0 & 95 & 83 \\
23 & 86.6 & 42.0 & 97 & 80 \\
24 & 86.7 & 42.2 & 95 & 83 \\
25 & 86.6 & 42.0 & 95 & 85 \\
26 & 86.7 & 42.2 & 96 & 86 \\
27 & 87.8 & 44.9 & 75 & 77 \\
28 & 86.0 & 40.5 & 91 & 89 \\
\hline
\end{tabular}

${ }^{a} T_{m}$, Temperature at which thermally induced hyperchromicity reached one half its maximum value.

${ }^{b}$ At $60^{\circ} \mathrm{C}$ with reference strains of $S$. faecium subsp. casseliflavus.

the literature $(10,13)$. The $T_{m}$ 's of the streptococci ranged from 83.6 to $87.8^{\circ} \mathrm{C}$ with an average of $85.9 \pm 0.98^{\circ} \mathrm{C}$. The $\mathrm{G}+\mathrm{C}$ content ranged from 34.7 to 44.9 with an average of $40.4 \pm 2.4 \mathrm{~mol} \%$. Strain 4, the type strain of $S$. faecium subsp. casseliflavus, was found to have a $T_{m}$ of $86.6^{\circ} \mathrm{C}$.

Strain 27 , reported as atypical of either $S$. faecium or $S$. faecalis (14), was found to have a $T_{m}$ of $87.8^{\circ} \mathrm{C}$. Strain 13 , reported (14) as being similar to strains of $S$. faecium subsp. casselifla. vus, had a $T_{m}$ of $85.0^{\circ} \mathrm{C}$. Strain 12 was reported as $S$. faecium-like (14) and had a $T_{m}$ of $86.6^{\circ} \mathrm{C}$.

DNA-DNA reassociation at $60^{\circ} \mathrm{C}$. Several of the yellow-pigmented strains tested showed a high degree of DNA homology with reference strains 4 and 5 . All of these strains exhibited high $T_{m}$ 's and G+C contents as compared with those strains not exhibiting high homology with strains 4 and 5 (Table 3).

The DNA-DNA reassociation data and the $T_{m}$ 's of the DNAs allowed division of the yellow- 
pigmented strains into two groups (Table 3). Group I exhibited $T_{m}$ 's equal to or less than $86.0^{\circ} \mathrm{C}$, DNA base $(\mathrm{G}+\mathrm{C})$ compositions equal to or less than $40.5 \mathrm{~mol} \%$, and low reassociation (4 to $41 \%$ ) with strains 4 and 5 . Group II includes strains with $T_{m}$ 's equal to or greater than $86.0^{\circ} \mathrm{C}$, $\mathrm{G}+\mathrm{C}$ contents equal to or greater than $\mathbf{4 0 . 5}$ $\mathrm{mol} \%$, and high reassociation with strains 4 and 5 . The group with the lower $T_{m}$ 's had a mean $T_{m}$ of $85.0 \pm 0.7^{\circ} \mathrm{C}$, which corresponds to a mean $\mathrm{G}+\mathrm{C}$ content of $38.1 \mathrm{~mol} \%$. The group with the higher values had a mean $T_{m}$ of $86.6 \pm 0.4^{\circ} \mathrm{C}$, corresponding to a mean $\mathrm{G}+\mathrm{C}$ content of 42.0 $\mathrm{mol} \%$.

Strains 14 and 28 had $T_{m}$ 's of $86.0^{\circ} \mathrm{C}$ and were placed in groups I and II, respectively, on the basis of the ability of their DNA to reassociate with that of strains 4 and 5 .

Intermediate levels of DNA-DNA reassociation with strains 4 and 5 were obtained with strains 9,11 , and 15 . All of the strains which had high and intermediate levels of homology with strains 4 and 5, and some which showed poor levels of binding with strains 4 and 5, were examined further in reassociation experiments with incubation temperatures of 70 and $75^{\circ} \mathrm{C}$.

DNAs in homologous reactions consistently exhibited 80 to $90 \%$ reassociation (Table 4). Results were corrected for nonspecific binding ( 3 to $4 \%$ ) and were normalized to the homologous reaction. Unlabeled DNA from strains 1 and 2 of $S$. faecium hybridized with labeled DNA from $S$. faecalis strain 3 at a level of $95 \%$ or greater. Unlabeled DNA from strain 3 bound $90 \%$ of labeled DNA from strain 2. DNA from all of the yellow-pigmented strains showed low (less than $25 \%$ ) homology with DNA from strains of $S$. faecium and $S$. faecalis.

Thermal elution studies. To test the stability of duplexes formed during the reassociation studies at $60^{\circ} \mathrm{C}$ incubation, thermal stability studies were done on duplexes which had been incubated at $70^{\circ} \mathrm{C}$ and on those which had been incubated at $75^{\circ} \mathrm{C}$, and a thermal elution midpoint $\left(T_{m(e)}\right)$ was determined for each duplex (Tables 5 and 6). $T_{m(e)}$ is the temperature at which $50 \%$ of the DNA bound to the hydroxyapatite is dissociated. The higher temperatures provide more stringent conditions than does $60^{\circ} \mathrm{C}$ and prevent the reassociation of all but the highly complementary duplexes. For each reaction mixture, whether incubated at 70 or at $75^{\circ} \mathrm{C}$, the thermal binding index was calculated. The thermal binding index is the ratio of binding at 70 or $75^{\circ} \mathrm{C}$ to that at $60^{\circ} \mathrm{C}$. The thermal binding index approaches 1.0 in closely related organisms (4). In general, the following relationships were shown. Those strains which exhibited greater than 50\% DNA-DNA reassociation with strains
TABLE 4. Reassociation of DNA from reference strains of $S$. faecium, $S$. faecium subsp. casseliflavus, and $S$. faecalis with DNA from group $I$ and group II strains

\begin{tabular}{|c|c|c|c|c|}
\hline \multirow{3}{*}{$\begin{array}{l}\text { Source of unla- } \\
\text { beled DNA }\end{array}$} & \multicolumn{4}{|c|}{$\begin{array}{l}\text { \% Hybridization }{ }^{n} \text { of unlabeled DNA with } \\
\text { labeled DNA from: }\end{array}$} \\
\hline & \multirow{2}{*}{$\begin{array}{l}\text { S. faecium } \\
\text { strain } 2\end{array}$} & \multicolumn{2}{|c|}{$\begin{array}{l}\text { S. faecium subsp. } \\
\text { casseliflavus }\end{array}$} & \multirow{2}{*}{$\begin{array}{l}\text { S. faecalis } \\
\text { strain } 3\end{array}$} \\
\hline & & strain 4 & strain 5 & \\
\hline \multicolumn{5}{|l|}{ S. faecium strains } \\
\hline 1 & 97 & 14 & 17 & 95 \\
\hline 2 & 100 & 15 & 11 & 96 \\
\hline \multicolumn{5}{|l|}{ S. faecalis strain } \\
\hline 3 & 90 & 17 & 12 & 100 \\
\hline \multicolumn{5}{|l|}{$\begin{array}{l}\text { S. faecium subsp. } \\
\text { casseliflavus } \\
\text { strains }\end{array}$} \\
\hline 4 & 8 & 100 & 77 & 7 \\
\hline 5 & 13 & 75 & 100 & 10 \\
\hline \multicolumn{5}{|l|}{$\begin{array}{l}\text { Yellow-pigmented } \\
\text { strains }\end{array}$} \\
\hline \multicolumn{5}{|l|}{ Group I } \\
\hline 6 & 14 & 16 & 4 & 8 \\
\hline 7 & 5 & 19 & 9 & 4 \\
\hline 8 & 9 & 7 & 8 & 4 \\
\hline 9 & 4 & 41 & 22 & 2 \\
\hline 10 & 12 & 7 & 7 & 8 \\
\hline 11 & 1 & 26 & 22 & 11 \\
\hline 12 & 13 & 9 & 6 & 21 \\
\hline 13 & 10 & 12 & 9 & 4 \\
\hline 14 & 4 & 9 & 13 & 3 \\
\hline 15 & 16 & 32 & 22 & 12 \\
\hline \multicolumn{5}{|l|}{ Group II } \\
\hline 16 & 9 & 90 & 88 & 8 \\
\hline 17 & 8 & 77 & 99 & 13 \\
\hline 18 & 1 & 86 & 99 & 11 \\
\hline 19 & 5 & 87 & 77 & 3 \\
\hline 20 & 10 & 96 & 82 & 11 \\
\hline 21 & 21 & 79 & 94 & 21 \\
\hline 22 & 7 & 95 & 83 & 5 \\
\hline 23 & 8 & 97 & 80 & 8 \\
\hline 24 & 9 & 95 & 83 & 6 \\
\hline 25 & 9 & 95 & 85 & 5 \\
\hline 26 & 17 & 96 & 86 & 11 \\
\hline 27 & 9 & 75 & 77 & 2 \\
\hline 28 & 20 & 91 & 89 & 12 \\
\hline
\end{tabular}

${ }^{a}$ Expressed as percentage of homologous reaction values.

4 and 5 at $60^{\circ} \mathrm{C}$ also showed greater than $50 \%$ binding at $70^{\circ} \mathrm{C}$, as well as at $75^{\circ} \mathrm{C}$, when tested at this temperature. Those strains which showed less than $50 \%$ binding with strains 4 and 5 at $60^{\circ} \mathrm{C}$ showed even less binding at 70 and $75^{\circ} \mathrm{C}$.

For each heterologous reaction, $\Delta T_{m(e)}$ was calculated (Table 5). $\Delta T_{m(e)}$ is the difference between the $T_{m(e)}$ of the heterologous and homologous reactions. It has been estimated that the presence of each $1.0 \%$ mismatched bases lowers the thermal stability about $1^{\circ} \mathrm{C}(2)$.

The data were plotted, and the resulting thermal elution curves are shown in Fig. 1 to 4 . Homologous reactions are shown in Fig. 1 and 2, 
TABLE 5. Reassociation of DNAs from reference strains with DNAs from other strains of S. faecium subsp. casseliflauus

\begin{tabular}{lccc}
\hline \multirow{2}{*}{$\begin{array}{c}\text { Reaction mix- } \\
\text { tures }^{a}\end{array}$} & \multicolumn{3}{c}{$\begin{array}{c}\text { \% DNA-DNA reassociation } \\
\text { at: }\end{array}$} \\
\cline { 2 - 4 } & \multicolumn{4}{c}{ with incubation } \\
\hline $4 / 4$ & $85 \pm 1.7$ & $82 \pm 2.8$ & $83 \pm 1.3$ \\
$4 / 5$ & $66 \pm 3.6$ & $61 \pm 2.0$ & $63 \pm 2.7$ \\
$4 / 9$ & 36 & 14 & 3 \\
$4 / 16$ & 68 & 58 & $-{ }^{\circ} \mathrm{C}$ \\
$4 / 17$ & 68 & 56 & 60 \\
$4 / 18$ & 68 & 64 & 60 \\
$4 / 19$ & 73 & 66 & - \\
$4 / 20$ & 82 & 69 & - \\
$4 / 21$ & 67 & 58 & 63 \\
$4 / 11$ & 24 & 11 & - \\
$4 / 25$ & 72 & 64 & 75 \\
$4 / 12$ & 9 & 9 & - \\
$4 / 27$ & 75 & 72 & - \\
$4 / 15$ & 29 & 16 & - \\
$5 / 5$ & $87 \pm 2.1$ & $85 \pm 1.4$ & $85 \pm 2.9$ \\
$5 / 4$ & $67 \pm 2.0$ & $58 \pm 3.3$ & $56 \pm 3.2$ \\
$5 / 9$ & 22 & 9 & - \\
$5 / 17$ & 79 & 79 & 79 \\
$5 / 18$ & 83 & 80 & - \\
$5 / 19$ & 61 & 60 & 60 \\
$5 / 20$ & 72 & 64 & 62 \\
$5 / 21$ & 74 & 60 & 72 \\
$5 / 11$ & 21 & 9 & - \\
$5 / 25$ & 56 & 51 & 60 \\
$5 / 12$ & 7 & 4 & - \\
$5 / 27$ & 69 & 65 & 61 \\
$5 / 15$ & 21 & 9 & - \\
\hline & & 9 & - \\
\hline
\end{tabular}

${ }^{a}$ The labeled strain is represented by the number to the left of the slash mark, and the unlabeled strain is represented by the number to the right of the slash.

${ }^{b}$ All values represent actual nonnormalized experimental values.

c_, No experimental determination.

and representative heterologous reactions are shown in Fig. 3 and 4. The homologous reactions exhibited sigmoid curves. The heterologous reactions exhibiting low reassociation, and some of those exhibiting higher $(50 \%)$ reassociation at $60^{\circ} \mathrm{C}$ showed a significant increase in counts eluted as lower melting duplexes and perhaps less specific pairing of bases.

When homologous reassociations were carried out at 70 and $75^{\circ} \mathrm{C}$, the curves were virtually the same as those at $60^{\circ} \mathrm{C}$ (Fig. 1 and 2). The main differences appeared in the 0 to $10 \%$ section of the curve where the curve represents a relatively small number of counts. When heterologous reassociations were carried out at 70 or $75^{\circ} \mathrm{C}$ with strains which had given low reassociation at $60^{\circ} \mathrm{C}$, a large fraction of the duplexes eluted at low temperatures, showing that there had been some nonspecific binding at $60^{\circ} \mathrm{C}$ (Fig. 4). Heterologous reassociations at 70 and $75^{\circ} \mathrm{C}$ with those strains which displayed intermediate homology at $60^{\circ} \mathrm{C}$ gave varying results. Most of the heterologous reassociations exhibiting high binding at $60^{\circ} \mathrm{C}$ had elution patterns similar to those of homologous reactions and showed high reassociation at 70 and $75^{\circ} \mathrm{C}$ (Fig. 3).

Characteristic physiological properties of groups $I$ and II. Eight of the 10 strains in group I decarboxylated tyrosine, whereas all 14 strains tested in group II failed to decarboxylate tyrosine. Eight of the strains in group I fermented sorbitol, whereas 6 of the 15 in group II fermented the alcohol. Three of the strains in group I grew in broth with $6.5 \% \mathrm{NaCl}$, whereas 13 of 15 strains in group II did so.

\section{DISCUSSION}

The existence of a group of streptococci distinct from $S$ faecium and $S$. faecalis is shown by DNA-DNA reassociation. The organisms in this group (group II) consistently showed high (50\%) homology with the two reference strains of this group, strains 4 and 5, but showed little homology with strains of $S$. faecium and $S$. faecalis.

The purpose of this work was to examine the genetic relatedness among yellow-pigmented strains of group D streptococci. We also wished to determine whether any correlation existed between the physiological characteristics and the DNA homologies of the yellow-pigmented strains; therefore, strains which differed somewhat in their characteristics were included in this study. Because of the variation in physiological characteristics among the strains, one might expect a continuum in the degree of reassociation. Rather, we found division of the strains into two classes: those showing greater than $50 \%$ reassociation with the reference strains and those showing less than $50 \%$ reassociation with the reference strains, the majority of the latter showing less than $20 \%$ reassociation with strains 4 and 5 . Those eight strains which showed poor homology with the reference strains, like those which showed good homology, were variable in their physiological characteristics.

The pigment of $S$. faecium subsp. casseliflavus has been identified as a carotenoid (14), possibly a flavonol or a flavanone (11). In our experiments, we merely observed the pigment in isolated colonies on sucrose agar, in the pellet of cells centrifuged after $48 \mathrm{~h}$ of growth in tryptic soy broth, or in pellets of cells from which DNA was to be isolated. Strains $5,13,15,16,22$ to 26 , and 28 were observed to have a faint or fine yellow pigment. Strains 4, 6, 7, 10, 12, 14, 17 to 21 , and 27 had more intense yellow color. Strains 
TABLE 6. Relative binding of DNA-DNA reassociation reactions at 60,70 , and $75^{\circ} \mathrm{C}$

\begin{tabular}{|c|c|c|c|c|c|c|c|c|c|c|c|}
\hline \multirow{2}{*}{$\begin{array}{l}\text { Reaction } \\
\text { mixture }^{a}\end{array}$} & \multicolumn{3}{|c|}{$60^{\circ} \mathrm{C}$} & \multicolumn{4}{|c|}{$70^{\circ} \mathrm{C}$} & \multicolumn{4}{|c|}{$75^{\circ} \mathrm{C}$} \\
\hline & $\begin{array}{c}\text { \% Bind- } \\
\text { ing }^{h}\end{array}$ & $T_{m(e)^{c}}$ & $\Delta T_{m(e)}^{c}$ & $\begin{array}{l}\% \text { Bind- } \\
\text { ing }\end{array}$ & $T_{m(e)}$ & $\Delta T_{m(e)}$ & $\begin{array}{c}\mathrm{TBI}^{\prime \prime} \\
70^{\circ} \mathrm{C} / 60^{\circ} \mathrm{C}\end{array}$ & $\begin{array}{l}\text { \% Bind- } \\
\text { ing }\end{array}$ & $T_{m(e)}$ & $\Delta T_{m(e)}$ & $\begin{array}{c}\text { TBI } 75^{\circ} \mathrm{C} / \\
60^{\circ} \mathrm{C}\end{array}$ \\
\hline $4 / 4$ & 100 & 87.3 & $-^{e}$ & 100 & 87.3 & - & - & 100 & 88.6 & - & . - \\
\hline $4 / 5$ & 77 & 82.2 & 5.1 & 74 & 84.3 & 3.0 & 0.96 & 75 & 86.7 & 1.9 & 0.97 \\
\hline $4 / 9$ & 41 & - & - & 18 & 87.2 & 0.1 & 0.44 & - & - & - & - \\
\hline $4 / 16$ & 79 & 83.0 & 4.3 & 70 & 85.5 & 1.8 & 0.89 & - & - & - & - \\
\hline $4 / 17$ & 79 & 82.0 & 5.3 & 68 & 84.5 & 2.8 & 0.86 & 71 & 86.5 & 2.1 & 0.90 \\
\hline $4 / 18$ & 80 & 83.5 & 3.8 & 78 & 84.4 & 2.9 & 0.98 & 71 & 86.8 & 1.8 & 0.89 \\
\hline $4 / 19$ & 86 & 85.6 & 1.7 & 80 & 86.7 & 0.6 & 0.93 & - & - & - & - \\
\hline $4 / 20$ & 96 & 85.8 & 1.5 & 84 & 86.5 & 0.8 & 0.88 & - & - & - & - \\
\hline $4 / 21$ & 78 & 81.9 & 5.4 & 70 & 84.0 & 3.3 & 0.90 & 75 & 86.0 & 1.6 & 0.96 \\
\hline $4 / 11$ & 26 & 82.8 & 4.5 & 11 & 84.3 & 3.0 & 0.42 & - & - & - & - \\
\hline $4 / 25$ & 84 & 85.6 & 1.7 & 77 & 85.4 & 1.9 & 0.92 & 90 & 88.2 & 0.4 & 1.07 \\
\hline $4 / 12$ & 08 & 84.8 & 2.5 & 09 & 85.8 & 1.5 & 1.12 & - & - & - & - \\
\hline $4 / 27$ & 88 & 87.3 & 0.0 & 87 & 87.2 & 0.1 & 0.99 & - & - & - & - \\
\hline $4 / 15$ & 32 & 83.2 & 4.1 & 18 & 85.9 & 1.4 & 0.56 & - & - & - & - \\
\hline $5 / 5$ & 100 & 87.8 & - & 100 & 88.0 & - & - & 100 & 88.7 & - & - \\
\hline $5 / 4$ & 76 & 83.8 & 4.0 & 68 & 85.5 & 2.5 & 0.89 & 65 & 86.3 & 2.4 & 0.86 \\
\hline $5 / 9$ & 23 & 83.9 & 3.9 & 09 & 85.8 & 2.2 & 0.39 & - & - & - & - \\
\hline $5 / 16$ & 80 & 79.5 & 8.3 & 78 & 84.9 & 3.1 & 0.98 & - & - & - & - \\
\hline $5 / 17$ & 80 & 84.7 & 3.1 & 93 & 88.2 & 0.2 & 1.03 & 95 & 88.5 & 0.2 & 1.06 \\
\hline $5 / 18$ & 95 & 87.2 & 0.6 & 94 & 87.9 & 0.1 & 0.99 & - & - & - & - \\
\hline $5 / 19$ & 69 & 82.5 & 5.3 & 70 & 85.0 & 3.0 & 1.01 & 70 & 86.4 & 2.3 & 1.01 \\
\hline $5 / 20$ & 82 & 83.3 & 4.5 & 75 & 84.7 & 3.3 & 0.91 & 72 & 87.1 & 1.6 & 0.88 \\
\hline $5 / 21$ & 85 & 85.9 & 1.9 & 70 & 83.6 & 4.4 & 0.82 & 84 & 87.5 & 1.2 & 0.99 \\
\hline $5 / 11$ & 22 & 82.7 & 5.1 & 08 & 87.0 & 1.0 & 0.36 & - & - & - & - \\
\hline $5 / 25$ & 63 & 84.4 & 3.4 & 59 & 84.6 & 3.4 & 0.94 & 70 & 86.6 & 2.1 & 1.11 \\
\hline $5 / 12$ & 06 & 84.7 & 3.1 & 03 & 84.8 & 3.2 & 0.50 & - & - & - & - \\
\hline $5 / 27$ & 79 & 84.0 & 2.8 & 76 & 84.5 & 3.5 & 0.96 & 71 & 86.6 & 2.1 & 0.90 \\
\hline $5 / 15$ & 22 & 78.3 & 9.5 & 09 & 84.7 & 3.3 & 0.41 & - & - & - & - \\
\hline
\end{tabular}

${ }^{a}$ The labeled strain number is to the left of the slash mark, and the unlabeled strain is to the right.

${ }^{b}$ All percentages are normalized to homologous reactions.

' $T_{m(e)}$ is the temperature at which half of the DNA bound to hydroxyapatite is eluted. $\Delta T_{m(e)}$ denotes the difference between $T_{m(e)}$ for the appropriate homologous DNA reaction under consideration (2).

${ }^{2}$ TBI $70^{\circ} \mathrm{C} / 60^{\circ} \mathrm{C}$ and TBI $75^{\circ} \mathrm{C} / 60^{\circ} \mathrm{C}$ denote the thermal binding index, defined as the ratio of binding at $70^{\circ} \mathrm{C}$ to that at $60^{\circ} \mathrm{C}$ and the ratio of binding at $75^{\circ} \mathrm{C}$ to that at $60^{\circ} \mathrm{C}$, respectively (2).

${ }^{\circ}$-, No experimental determination.

8 and 9 had an extremely bright yellow pigment. There seems to be no group correlation of intensity of pigmentation and DNA homology.

Based on their physiological characteristics, the strains with which we worked would ordinarily be classified either as atypical strains of $S$. faecalis or $S$. faecium or as strains intermediate between these two species, since they have some characteristics of both and some characteristics not shared by these two species. Moreover, none of the yellow-pigmented strains hybridized at a level of more than $21 \%$ with strains of either $S$. faecium or $S$. faecalis. Thus, according to the criteria proposed by Johnson (8), they are at most only distantly related to these species.

The DNA of the pigmented streptococci of group II hybridized at a level of at least $75 \%$ with the DNA of strains 4 and 5 . Thus, this group appears to constitute a distinct taxon. The strains in group I, for the most part, have a DNA complement which hybridized at a level of about $10 \%$ with strains 4 and 5 . These strains appear to be only distantly related to the taxon centering around strains 4 and 5.

Reassociation experiments appear to be a useful tool in determining which physiological characteristics should be weighted in a scheme for identifying bacteria. Based on the results of these experiments, it appears that there are certain physiological characteristics which should carry more weight than others in the identification of the pigmented streptococci. The characteristics to be emphasized are tyrosine decarboxylation, sorbitol fermentation, and growth in $6.5 \% \mathrm{NaCl}$.

On the basis of fatty acid content, Amstein and Hartman (1) found sufficient differences 


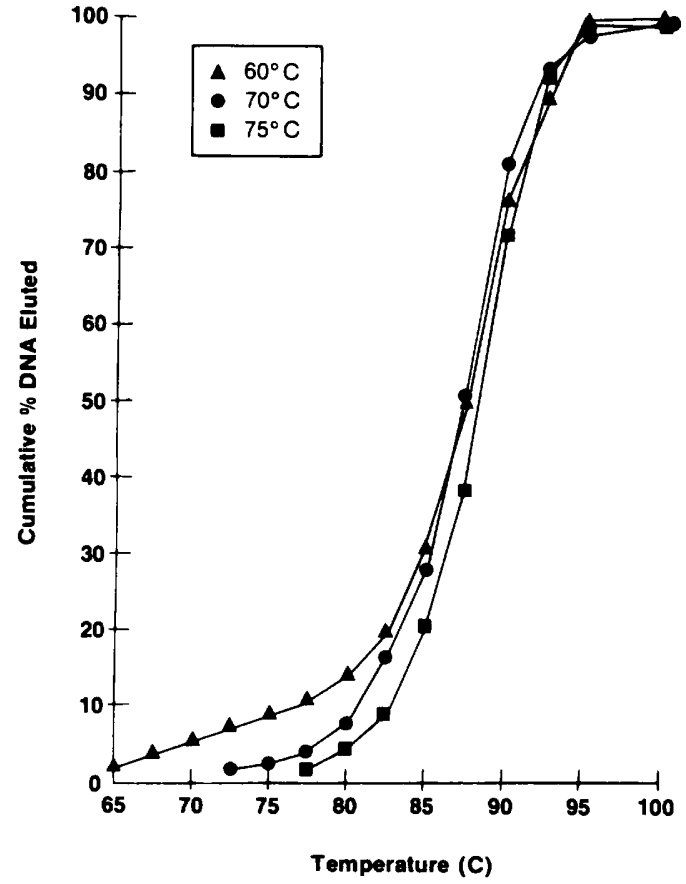

Fig. 1. Thermal elution from hydroxyapatite of duplexes of ${ }^{32}$ P.labeled and unlabeled DNA from strain 4.

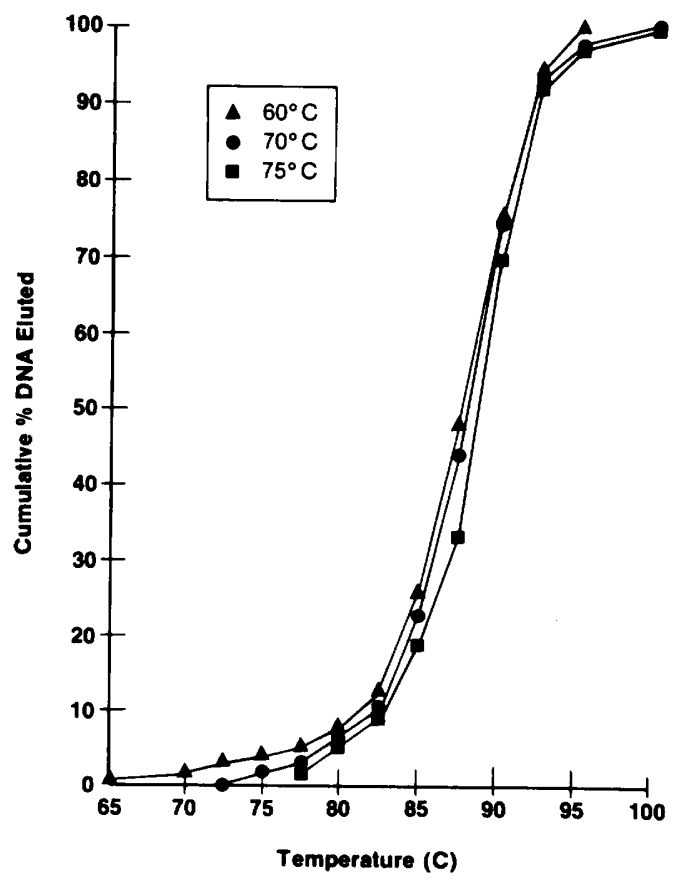

FIG. 2. Thermal elution from hydroxyapatite of duplexes of ${ }^{32} P$-labeled and unlabeled DNA from strain 5.

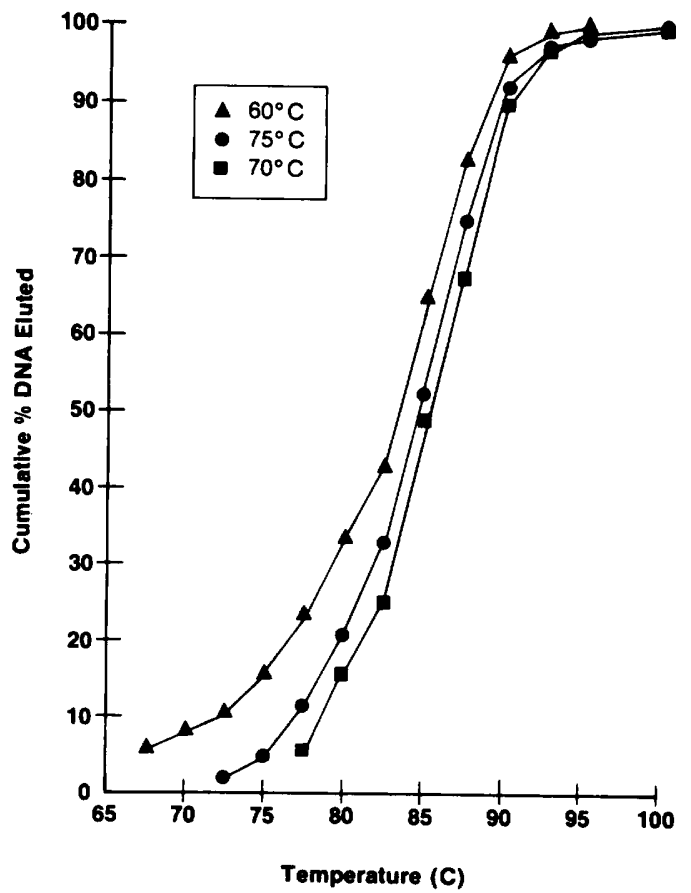

Fig. 3. Thermal elution from hydroxyapatite of duplexes of ${ }^{32} P$-labeled DNA from strain 5 and unlabeled DNA from strain 20.

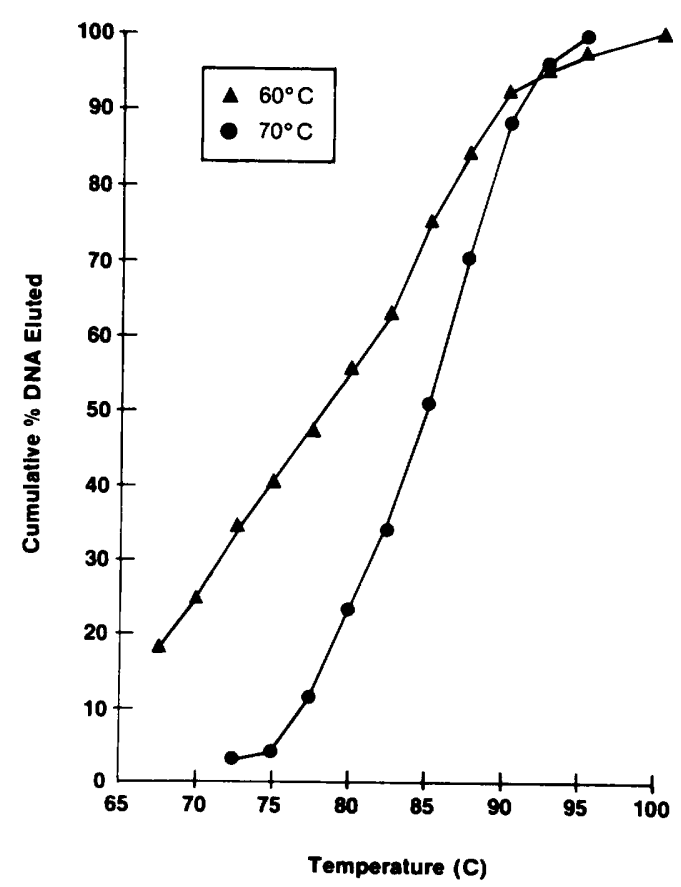

Fig. 4. Thermal elution from hydroxyapatite of duplexes of ${ }^{32} P$-labeled DNA from strain 5 and unlabeled DNA from strain 15. 
between strains of $S$. faecium subsp. casseliflavus and other strains of $S$. faecium to conclude that $S$. faecium subsp. casseliflavus "deserves varietal, if not species, status." The possibility of assigning species status to $S$. faecium subsp. casseliflavus was further suggested by our finding (13) that the DNA of an authentic strain of $S$. faecium subsp. casseliflavus has negligible sequence homology with the DNA of an authentic strain of $S$. faecium and by the physiological differences that we have just reviewed. We deferred proposing a change in the taxon, however, pending an examination of the DNA hybridization behavior of additional yellow-pigmented strains. As reported here, we have now tested 25 different yellow-pigmented group D streptococci and have found none which exhibits significant DNA sequence homology with $S$. faecium. Therefore, we now feel justified in proposing that $S$. faecium subsp. casseliflavus be elevated to the rank of species and be designated Streptococcus casseliflavus (Mundt and Graham) comb. nov. Our earlier suggestion (13) that the yellow-pigmented group D streptococci are not a homogeneous group is further borne out by the results reported here, and we conclude that the strains we have placed in group I should be excluded from the proposed species. The status of the group I strains cannot be established without further work.

\section{ACKNOWLEDGMENT}

We thank W. R. Chesbro for providing cultures of strains 12,13 , and 27.

\section{REPRINT REQUESTS}

Address reprint requests to: W. S. Riggsby, Department of Microbiology, University of Tennessee, Knoxville, Tennessee 37916 .

\section{LITERATURE CITED}

1. Amstein, C. F., and P. A. Hartman. 1973. Differentiation of some enterococci by gas chromatography. J. Bacteriol. 113:38-41.

2. Brenner, D. J., G. R. Fanning, K. E. Johnson, R. V. Citarella, and S. Falkow. 1969. Polynucleotide sequence relationship among members of the Enterobacteriaceae. J. Bacteriol. 98:637-650.

3. Brenner, D. J., G. R. Fanning, A. V. Rake, and K. E. Johnson. 1969. Batch procedure for thermal elution of DNA from hydroxyapatite. Anal. Biochem. 28:447 459.

4. Brenner, D. J., G. R. Fanning, F. J. Skerman, and S. Falkow. 1972. Polynucleotide sequence divergence among strains of Escherichia coli and closely related organisms. J. Bacteriol. 109:953-965.

5. Britten, R. J., and D. E. Kohne. 1966. Nucleotide sequence repetition in DNA. Carnegie Inst. Washington Yearb. 65:78-106.

6. Clausen, T. 1968. Measurement of ${ }^{32} \mathrm{P}$ activity in a liquid scintillation counter without use of scintillator. Anal. Biochem. 22:70-73.

7. De Ley, J. 1969. Compositional nucleotide distribution and theoretical prediction of homology in bacterial DNA. J. Theor. Biol. 22:89-116.

8. Johnson, J. L. 1973. Use of nucleic-acid homologies in the taxonomy of anaerobic bacteria. Int. J. Syst. Bacteriol. 23:308-315.

9. Marmur, J. 1961. A procedure for the isolation of deoxyribonucleic acid from micro-organisms. J. Mol. Biol. 3: 208-218.

10. Marmur, J., and P. Doty. 1962. Determination of the base composition of deoxyribonucleic acid from its thermal denaturation temperature. J. Mol. Biol. 5:109-118.

11. Mundt, J. O., and W. F. Graham. 1968. Streptococcus faecium var. casseliflavus, nov. var. J. Bacteriol. 95: 2005-2009.

12. Mundt, J. O., W. F. Graham, and I. E. McCarty. 1967. Spherical lactic acid-producing bacteria of southerngrown raw and processed vegetables. Appl. Microbiol. 15:1303-1308.

13. Roop, D. R., J. O. Mundt, and W. S. Riggeby. 1974. Deoxyribonucleic acid hybridization studies among some strains of group $\mathrm{K}$ and group $\mathrm{N}$ streptococci. Int. J. Syst. Bacteriol. 24:330-337.

14. Taylor, R. F., M. Ikawa, and W. R. Chesbro. 1971. Carotenoids in yellow-pigmented enterococci. J. Bacteriol. 105:676-678. 